\title{
Radiffe tār be revāyat va ejrā-ye ostād Morteḍ̄a Neydāvūd. 4 CDs avec livret de présentation (persan et anglais). M.CD-180, Tehrān, Māhūr, 2005. [Radīf de tār selon le maître Morteḍā Neydāvūd]
}

\section{Sāsān Fāṭemī}

\section{OpenEdition}

\section{Journals}

Édition électronique

URL : http://journals.openedition.org/abstractairanica/7992

DOI : $10.4000 /$ abstractairanica.7992

ISSN : 1961-960X

Éditeur :

CNRS (UMR 7528 Mondes iraniens et indiens), Éditions de l'IFRI

Édition imprimée

Date de publication : 15 mai 2007

ISSN : 0240-8910

Référence électronique

Sāsān Fātemī, « Radîf-e tār be revāyat va ejrā-ye ostād Morteḍā Neydāvūd. 4 CDs avec livret de présentation (persan et anglais). M.CD-180, Tehrān, Māhūr, 2005. [Radîf de tār selon le maître Mortedā Neydāvūd] », Abstracta Iranica [En ligne], Volume 28 | 2007, document 526, mis en ligne le 18 septembre 2007, consulté le 25 septembre 2020. URL : http://journals.openedition.org/ abstractairanica/7992 ; DOI : https://doi.org/10.4000/abstractairanica.7992

Ce document a été généré automatiquement le 25 septembre 2020.

Tous droits réservés 
Radīf-e tār be revāyat va ejrā-ye ostād Morteḍ̄ Neydāvū d. 4 CDs avec livret de présentation (persan et anglais). M.CD-180, Tehrān, Māhūr, 2005. [Radîf de tār selon le maître Morteḍā Neydāvūd]

\section{Sāsān Fāțemī}

1 Le radif instrumental de la musique classique iranienne selon un maître incontesté de cette musique, interprété par lui-même alors qu'il était âgé de presque 70 ans. C'est en 1969 que les responsables de la Radio lui proposent d'enregistrer le radif instrumental complet, ce qu'il n'hésite pas à accepter en se mettant pendant deux ans à accomplir cette tâche sans demander de rémunération. Ces CDs sont les résultats de cette entreprise, publiée pour la première fois.

\section{INDEX}

Thèmes : 17.1.Musique 
AUTEURS

SĀSĀN FĀTEMĪ

Université de Téhéran 